\title{
PENGARUH PENGGUNAAN APLIKASI EDLINK DAN APLIKASI WHATSAPP TERHADAP KEMANDIRIAN BELAJAR MAHASISWA PGSD
}

\author{
Hartinawanti ${ }^{1}$, Nurhayati Selvi ${ }^{2}$, Wahyullah Alannasir ${ }^{3}$ \\ ${ }^{1}$ Universitas Muslim Buton, ${ }^{2,3}$ Universitas Islam Makassar \\ Jln. Betoambari Kota Baubau Sultra ${ }^{1}$, Jln. Perintis Kemerdekaan Kota Makassar Sulsel ${ }^{2}$, \\ Jln. Perintis Kemerdekaan Kota Makassar Sulsel ${ }^{2}$ \\ tina53344@gmail.com¹, nurhayatiselvi778@gmail.com²,wahyullah69@gmail.com³
}

\begin{abstract}
This study aims to increase the learning independence of PGSD students of FKIP Makassar Islamic University through the use of the edlink and whatsApp application. The research method is a quantitative approach, the type of experimental research using Quasi Experiment Design. Data collection techniques through questionnaires and documentation. The sampling technique used in this study is saturated sampling and heterogeneous group division. The data analysis technique used descriptive statistics and inferential statistics. The results of the study prove that the learning independence of PGSD FKIP students at the Islamic University of Makassar in online learning with the use of the edlink application (Experiment) on the pretest was in the low category and the postest was in the high category while the control class on the pretest was in the low category and the postest was in the medium category; There are differences in learning independence in the experimental class and the control class, so it is obtained that the use of the edlink application has a significant effect on the learning independence of PGSD FKIP students of Makassar Islamic University.

Keywords: edlink, whatsapp, independent learning
\end{abstract}

Abstrak: Penelitian ini bertujuan untuk meningkatkan kemandirian belajar mahasiswa PGSD FKIP Universitas Islam Makassar melalui penggunaan aplikasi edlink dan whatsapp. Metode penelitian ini yaitu pendekatan kuantitatif, jenis penelitian eksperimen dengan menggunakan Quasi Experiment Design. Teknik pengumpulan data melalui kuesioner dan dokumentasi. Teknik sampling yang digunakan penelitian ini yaitu sampling jenuh dan pembagian kelompok dilakukan secara heterogen. Teknik analisis data menggunakan statistik deskriptif dan statistik inferensial. Hasil penelitian membuktikan bahwa Kemandirian belajar mahasiswa PGSD FKIP Universitas Islam Makassar dalam pembelajaran daring dengan penggunaan aplikasi edlink (eksperimen) pada pretest berada pada kategori rendah dan pada postest berada pada kategori tinggi sedangkan kelas kontrol pada pretest berada pada kategori rendah dan postest berada pada kategori sedang; Terdapat perbedaan kemandirian belajar pada kelas eksperimen dan kelas kontrol, sehingga diperoleh penggunaan aplikasi edlink memiliki pengaruh yang signifikan terhadap kemandirian belajar mahasiswa PGSD FKIP Universitas Islam Makassar.

Kata Kunci: edlink, whatsapp, kemandirian belajar 
$\mathrm{P}$

endidikan dan pembangunan memiliki keterikatan yang sangat kuat. Hasil dari pendidikan dapat membuat pembangunan suatu bangsa meningkat secara terus-menerus dan berkelanjutan. Pendidikan juga semestinya dapat menjamin proses peningkatan kemampuan manusianya dalam melakukan pembangunan secara terus menerus. Pendidikan menyangkut pembangunan dalam hal perubahan sosial. (Triwiyanto, 2021) berpendapat bahwa pendidikan praktek-praktek di sekolah memiliki keterikatan dengan pembangunan suatu bangsa. Berkenaan dengan keterkaitan pendidikan dan pembangunan tersebut tentunya yang paling diharapkan dari hasil pendidikan adalah lahirnya sumber daya manusia yang mampu membangun bangsa.

Jalur sistem pendidikan diatur melalui undang-undang sistem pendidikan nasional. Pendidikan merupakan suatu wadah peserta didik untuk dapat meningkatkan potensi dirinya sehingga tercapai tujuan pendidikan. Pendidikan tinggi diselenggarakan dengan system terbuka (Triwiyanto 2021:122). Pendidikan di dalamnya membangun interaksi melalui pendidik, peserta didik serta lingkungan pembelajaran. Syah (2014) mengemukakan bahwa kemampuan melakukan suatu perubahan adalah makna dan batasan dalam belajar. Karena dengan belajar akan membuat kemampuan berubah, sehingga manusia dapat mengembangkan segala potensinya lebih jauh. Belajar memiliki peranan penting untuk memelihara tatanan kehidupan sekelompok masyarakat ditengah persaingan global dengan bangsabangsa lain yang lebih maju dalam dunia pendidikan.

Namun kenyataan tragis yang bisa muncul dari hasil belajar, contoh: tidak jarang banyak orang yang berpendidikan tinggi malah membuat orang lain terpuruk. Dari hasil belajar ilmu tekhnologi, seumpamanya tak sedikit digunakan orang dalam melakukan penipuan. Saat ini banyak terjadi pencurian hanya melalui teknologi dan tanpa bertemu langsung. Hanya menggunakan telepon orang dapat meraup isi rekening orang lainnya. Walaupun hasil belajar dari sekelompok manusia tertentu memiliki pengaruh negatif, kegiatan belajar mempunyai peranan yang sangat bermakna, karena belajar itu berkedudukan sebagai bekal untuk keberlangsungan kehidupan umat manusia (Syah 2014:62).

Menurut Tirtaraharja \& Sulo Lipu La Sulo, 2005) bahwa kemandirian dalam belajar dimaknai selaku kegiatan belajar yang keberlangsungannya lebih cenderung atas kemauan, pilihan serta tanggung jawab sendiri. Jika seseorang memiliki kemandirian dalam belajar yang tinggi, akan mudah baginya menyerap informasi (pelajaran) yang pada hasilnya dapat 
memecahkan

masalah-masalah

pembelajaran yang dihadapi.

Meluasnya wabah penyakit Covid19 (Corona Virus Disease 2019) bermula desember 2019 hingga saat ini mewajibkan semua kegiatan proses pembelajaran peserta didik dilakukan di rumah untuk sementara waktu hingga waktu yang belum dapat ditentukan. Hal ini dianggap penting dilakukan untuk mengurangi sentuhan langsung seperti bersalaman, berpegang tangan, guna dapat mengakhiri penyebaran penyakit Covid-19. Untuk menyelesaikan proses kegiatan belajar mengajar tahun akademik yang berjalan ini, pemangku kebijakan/ pemerintah membuat keputusan bahwa pembelajaran tahun akademik ini dapat dilakukan via pembelajaran media daring (dalam jaringan), baik dengan menggunakan leptop, PC atau smartphone.

Diantara alternatif yang mudah digunakan yaitu platform edlink dan whatsappp. Edlink merupakan sebuah aplikasi berlandas android yang secara eksklusif untuk dunia pendidikan yang mempunyai tujuan untuk memfasilitasi ruang belajar antara guru dan peserta didik dalam proses kegiatan belajar mengajar serta dapat dijalankan di mana dan kapan saja sehingga waktu untuk belajar lebih luwes. Kelas maya (online) sesungguhnya tidak memiliki perbedaan dengan kelas nyata. Dosen membuat kelas maya melalui media teknologi yang penggunaannya mudah dipahami oleh mahasiswa yang diampu. Setiap dosen wajib menciptakan iklim belajar yang efektif sejalan dengan apa yang sudah diagendakan sebelumnya.

Penggunaan aplikasi whatsApp bukan hanya digunakan untuk chatting saja, akan tetapi aplikasi whatsApp dapat juga digunakan untuk mendukung kegiatan proses pembelajaran daring. Salah satu fasilitas aplikasi whatsApp yakni grup whatsapp dapat dimanfaatkan dengan mudah untuk melangsungkan perkuliahan secara online (daring). Langkah-langkah membuat grup whatsApp yakni dosen harus menyimpan nomor-nomor hp mahasiswa yang mengambil mata kuliah yang diampu di kontak smartphone miliknya kemudian membuat grup pada aplikasi whatsapp sesuai nama mata kuliah tersebut. Penggunaan grup whatsapp oleh dosen dapat memberikan layanan kemudahan untuk melangsungkan pembelajaran secara online (daring) dan realtime. Bukan hanya itu, sistem pembelajaran secara online dan realtime, dosen juga dapat dengan mudah memantau setiap kehadiran mahasiswa yang tetap aktif mengikuti perkuliahan/ pembelajaran online yang berlangsung.

Penelitian terdahulu dilakukan oleh (Novandini \& Luta, 2019) dengan Pemanfaatan Kelas Virtual Sevima Edlink Untuk Memotivasi Mahasiswa Pendidikan Matematika Semester 1 Matakuliah 
Aljabar \& Trigonometri. Hasil penelitiannya menunjukkan pemanfaatan aplikasi Sevima Edlink cukup efektif dalam memotivasi dan membantu mahasiswa dalam belajar untuk mempersiapkan ujian remidi.

Selanjutnya oleh (Rahmasari et al., 2020) dengan Pengaruh Pembelajaran Online Terhadap Kemandirian Belajar Siswa Kelas II SD Muhammadiyah 17 Surabaya di Tengah Pandemi Covid-19. Hasil temuannya menunjukkan keuntungan dari melakukan pembelajaran online yang saat ini dilakukan seperti meningkatkan daya ingat siswa, memberikan wawasan yang luas dengan pengalaman mereka melalui teks, video dan audio serta orang tua juga lebih sering memantau anakanaknya dari rumah sehingga orang tua tidak khawatir dengan anaknya yang ketingggalan pelajaran.

Penelitian terdahulu lain oleh (Suryadi et al., 2018) dengan Penggunaan Sosial Media Whatsapp Dan Pengaruhnya Terhadap Disiplin Belajar Peserta Didik Pada Mata Pelajaran Pendidikan Agama Islam (Studi Kasus di SMK Analis Kimia YKPI Bogor). Hasil temuannya menunjukkan adanya pengaruh yang signifikan antara penggunaan sosial media whatsapp terhadap disiplin belajar peserta didik.

Berlandaskan uraian permasalahan di atas penulis tertarik melakukan kegiatan penelitian dengan judul "Pengaruh Penggunaan Aplikasi Edlink Dan Aplikasi WhatsApp Terhadap Kemandirian Belajar Mahasiswa PGSD”.

Berdasarkan uraian di latar belakang maka rumusan masalah dalam penelitian ini adalah: 1) bagaimana gambaran kemandirian belajar pada mahasiswa PGSD menggunakan aplikasi Edlink dan WhatsApp?; 2) apakah ada perbedaan kemandirian belajar pada mahasiswa PGSD menggunakan aplikasi Edlink dan WhatsApp?.

Tujuan yang ingin dicapai dalam penelitian ini adalah: 1) mengetahui kemandirian belajar pada mahasiswa PGSD menggunakan aplikasi Edlink dan WhatsApp; 2) menganalisa perbedaan kemandirian belajar pada mahasiswa PGSD menggunakan aplikasi Edlink dan WhatsApp.

Edlink merupakan sebuah aplikasi berlandas android yang secara eksklusif untuk dunia pendidikan untuk mendukung pendidik menyesuaikan waktu belajar, mengelola kelas secara online, dan menumbuhkan komunikasi virtual bersama mahasiswa. Dalam aplikasi edlink terdapat fitur-fitur yang memudahkan untuk menjalin interaksi antara pendidik dan peserta didiknya yaitu fitur berbagi tugas dalam kelas, fitur forum diskusi, info pembelajaran, jadwal deadline pengumpulan tugas yang bisa disetting dan 
survey tugas. Selain itu, dapat pula mengirim pesan pribadi agar dapat berkomunikasi secara pribadi dengan mahasiswa yang bertujuan untuk memberikan motivasi kepada mahasiswa serta sarana yang menjembatangi mahasiswa mengajukan pertanyaan terkait materi atau tugas yang berkaitan dengan kegiatan perkuliahan online (Novandini \& Luta, 2019).

Di dalam fitur forum kelas, pendidik mampu membuat tugas dengan mudah dan cepat yakni cukup mengklik berbagi informasi kemudian pilih tugas, pendidik langsung dapat memberi tugas, mengirim file, gambar bahkan link, untuk memberikan kemudahan bagi mahasiswa memahami tugas yang diberikan oleh pendidik.

Salah satu media sosial yang dipergunakan sebagai alat komunikasi chatting dengan saling mengirim pesan teks, telpon, gambar, bahkan panggilan video disebut whatsApp atau sering disebut aplikasi WA. Aplikasi ini aktif apabila pengguna kartu telpon memiliki kuota internet (Suryadi et al., 2018).

Lebih lanjut dijelaskan oleh (Hartanto, 2010), bahwa whatsApp merupakan aplikasi pesan dalam smartphone yang pada dasarnya mirip dengan aplikasi Blackberry Messenger. Pesan pada aplikasi whatsApp merupakan pesan lintas platform yang digunakan orang bertukar pesan tanpa mengeluarkan biaya SMS, karena pesan whatsApp menggunakan kuota internet selain itu juga dapat mengirim email, browsing web, dan lain-lain. Koneksi pada aplikasi whatsapp memakai koneksi 3G/4G dan dapat pula terhubung WiFi.

Dampak positif kemajuan ilmu teknologi informasi dan komunikasi dalam dunia pendidikan terkhusus pada proses kegiatan belajar mengajar dapat memajukan kualitas pendidikan. Sebagaimana dikemukakan (Rosenberg, 2001), bahwa seiring pesatnya penggunaan teknologi informasi dan komunikasi (TIK), ditemukan lima pergeseran dalam proses belajar mengajar yaitu; 1) pergeseran dari penelitian menjadi penampilan, pergeseran dari ruang kelas menjadi grup online, 3) pergeseran dari kertas menjadi tugas dalam bentuk file, 4) pergeseran fasilitas fisik menjadi fasilitas jaringan kerja, dan 5) pergeseran dari waktu siklus menjadi waktu nyata atau sistem yang menggunakan deadline.

Kemandirian merupakan sikap peserta didik dalam merealisasikan ambisi atau kemauannya secara faktual dan tidak berharap bantuan orang lain di sekitarnya, dalam hal ini peserta didik tersebut dikatakan mampu belajar sendiri, dapat memilih cara belajar yang efektif, mampu mengerjakan tugas dengan baik serta 
mampu melakukan semua aktivitas belajar secara mandiri (Rachmayani, 2014).

Kemandirian belajar menuntut peranan yang besar bagi peserta didik sehingga mereka berusaha melakukan berbagai kegiatan untuk mencapai tujuan belajar. (Darmayanti et al., 2004) menjelaskan mengenai kemandirian belajar merupakan gambaran belajar yang mempunyai tanggung jawab utama untuk merencanakan, melaksanakan, dan mengevaluasi usahanya. Sementara (Haryono, 2001) berpendapat bahwa kemandirian belajar harus diberikan kepada peserta didik agar mereka dapat bertanggung jawab dalam mengatur dan mendisiplinkan dirinya dalam meningkatkan kemampuan belajar atas kemauannya sendiri. selain bertanggung jawab, motivasi yang tinggi dari diri peserta didik sangat dibutuhkan dalam kemandirian belajar.

Indikator yang sangat mendasar (knowles) dalam kemandirian belajar yakni inisiatif. Dijelaskan kemandirian belajar menguraikan suatu proses individu memilih inisiatifnya sendiri tanpa bantuan orang lain untuk menelaah kebutuhan belajar, menyusun tujuan belajar, mengidentifikasi sumber belajar, menentukan pendekatan strategi belajar, dan melaksanakan evaluasi hasil belajar yang telah dicapai (Tahar \& Enceng, 2006).

\section{METODE}

Metode penelitian ini yaitu pendekatan kuantitatif dengan jenis penelitian eksperimen dan desain penelitian ini menggunakan Quasi Experiment Design. Teknik pengumpulan data yang digunakan yaitu kuesioner dan dokumentasi. Populasi penelitian ini yakni mahasiswa PGSD FKIP Universitas Islam Makassar dengan jumlah mahasiswa 54 orang. Teknik sampling yang digunakan yaitu sampling jenuh dan pembagian kelompok dilakukan secara heterogen sehingga diperoleh sampel yang terbagi 27 mahasiswa kelas kontrol dan 27 lagi kelas eksperimen dan terdaftar di semester genap tahun akademik 2019/2020. Teknik analisis data menggunakan statistik deskriptif dan statistik inferensial.

\section{HASIL DAN PEMBAHASAN}

\section{Hasil Penelitian}

Bagian ini akan dijabarkan gambaran hasil analisis data. Data instrumen-instrumen penelitian yang diperoleh dianalisis untuk memperoleh jawaban atas pertanyaan penelitian yang tercantum pada rumusan masalah. Dengan menganalisis data secara deskriptif dan inferensial jawaban atas pertanyaan tersebut dapat diperoleh.

Berlandaskan pengujian hipotesis pada hasil analisis data kemudian akan dilanjutkan pembahasan hasil analisis data 
yang telah diperoleh untuk mengetahui implikasi hasil analisis serta kaitannya dengan teori-teori yang mendasari penelitian ini.

\section{Gambaran Kemandirian Belajar Mahasiswa PGSD Sebelum dan Sesudah Penggunaan Aplikasi Edlink}

Kemandirian belajar diukur menggunakan instrumen berupa kuesioner yang berjumlah 22 item pertanyaan/ pernyataan. Setelah instrumen kuesioner kemandirian belajar diujikan diperoleh data pretest dan data posttest sebagai berikut.

Tabel 1. gambaran kemandirian belajar mahasiswa sebelum dan sesudah penggunaan aplikasi edlink

\begin{tabular}{|c|c|c|c|c|c|c|c|c|}
\hline \multicolumn{4}{|c|}{ Kelompok Eksperimen } & \multirow{3}{*}{$\begin{array}{c}\text { Interval / } \\
\text { Kategori }\end{array}$} & \multicolumn{4}{|c|}{ Kelompok Kontrol } \\
\hline \multicolumn{2}{|c|}{ Pretest } & \multicolumn{2}{|c|}{ posttest } & & \multicolumn{2}{|c|}{ Pretest } & \multicolumn{2}{|c|}{ Posttest } \\
\hline$f$ & $\%$ & $f$ & $\%$ & & $f$ & $\%$ & $f$ & $\%$ \\
\hline 0 & 0 & 7 & $\begin{array}{c}25,9 \\
2\end{array}$ & $\begin{array}{l}52-66 \\
\text { Tinggi }\end{array}$ & 0 & 0 & 0 & 0 \\
\hline 0 & 0 & 20 & $\begin{array}{c}74,0 \\
7\end{array}$ & $\begin{array}{c}37-51 \\
\text { Sedang }\end{array}$ & 0 & 0 & 27 & $\begin{array}{c}10 \\
0\end{array}$ \\
\hline 27 & 100 & 0 & 0 & $\begin{array}{c}22-36 \\
\text { Rendah }\end{array}$ & 27 & 100 & 0 & 0 \\
\hline 27 & 100 & 27 & 100 & Jumlah & 27 & $\begin{array}{c}10 \\
0\end{array}$ & 27 & $\begin{array}{c}10 \\
0\end{array}$ \\
\hline
\end{tabular}

Sumber: Data Primer Hasil Penelitian,2020

\section{a. Gambaran Kemandirian Belajar Mahasiswa Sebelum Penggunan Aplikasi Edlink}

Tabel 1 menunjukkan bahwa pada kelompok eksperimen sebelum penggunaan edlink, kemandirian belajar mahasiswa sebanyak 27 orang mahasiswa pada kategori rendah dengan persentase 100\%. Sedangkan pada kelompok kontrol sebelum pembelajaran (pretest) kemandirian sebanyak 27 orang mahasiswa pada kategori rendah dengan persentase $100 \%$.

Pretest dilakukan pada kelas eksperimen dan kontrol untuk mengetahui kemandirian mahasiswa terhadap pembelajaran daring menggunakan aplikasi. Berlandaskan hasil analisis terhadap data nilai pretest menunjukkan bahwa kelas eksperimen dan kelas kontrol memiliki kompetensi awal yang tidak berbeda secara signifikan. Nilai pretest kelas eksperimen dan kelas kontrol memiliki rata-rata yang kecil bahkan kategori kualifikasi rendah. Hal ini menunjukkan bahwa kemandirian awal mahasiswa kelas eksperimen rendah dan kemandirian awal kelas kontrol rendah.

\section{b. Gambaran Kemandirian Mahasiswa Sesudah Penggunaan Aplikasi Edlink}

Kuesioner kemandirian belajar untuk posttest serupa dengan pretest. Hal itu dilakukan agar menghindari terjadinya bias antara pretest dan posttest. Kuesioner kemandirian belajar mahasiswa untuk posttest berjumlah 22 item pertanyaan/pernyataan yang memiliki rentang nilai 22-66. Skor kemandirian belajar mahasiswa dengan menggunakan aplikasi edlink (kelompok eksperimen) diperoleh skor tertinggi adalah 66 dan terendah adalah 60. Mahasiswa yang 
diajarkan dengan menggunakan aplikasi whatsapp (kelas kontrol) memiliki skor tertinggi adalah 65 dan terendah adalah 60 .

Setelah penggunaan aplikasi edlink, kemandirian belajar mahasiswa mengalami peningkatan. Dapat dilihat dari kategori tinggi terdapat 7 orang mahasiswa memperoleh nilai persentase $25,92 \%$, pada kategori sedang terdapat 20 orang mahasiswa dengan nilai persentase $74,07 \%$, sementara pada kategori rendah sudah tidak ada lagi mahasiswa. Sedangkan pada kelompok kontrol tidak ada mahasiswa yang menduduki kategori tinggi, pada kategori sedang ditemukan 27 orang mahasiswa diperoleh nilai persentase $100 \%$, dan tidak ada mahasiswa lagi yang berada pada kategori rendah.

Postest dilakukan bagi kelas eksperimen dan kelas kontrol untuk mengetahui kemandirian akhir mahasiswa terhadap pembelajaran daring dengan mengggunakan aplikasi. Berlandaskan hasil analisis terhadap data nilai postest membuktikan bahwa kelas eksperimen dan kelas kontrol mempunyai kompetensi akhir yang berbeda secara signifikan. Nilai postest kelas eksperimen mempunyai ratarata yang yang berada pada kategori tinggi sedangkan kelas kontrol mempunyai ratarata yang berada pada kategori tinggi.

Berlandaskan tabel 1 di atas bisa dilihat sebaran data kelompok eksperimen dan kelompok kontrol. Pada tabel 1 membuktikan data kelompok eksperimen dengan kategori skor tinggi (52-66) sebesar 25,92\% (7 mahasiswa), berada pada kategori sedang (37-51) sebesar $74.07 \%$ (20 mahasiswa), serta skor rata-ratanya berada pada kategori tinggi (52-66) dengan skor 63,96. Dan data kelompok kontrol dengan kategori skor sedang (37-51) dengan jumlah 100\% (27 mahasiswa) serta pada kategori tinggi nilai rata-ratanya berada (52-66) dengan skor 62,03. Hal ini memperlihatkan bahwa tidak jauh berbeda sebaran data posttest kelas eksperimen dan kelas kontrol.

Berlandaskan nilai rata-rata kelas eksperimen dan kelas kontrol diperoleh perbedaan sebesar 1,93 $(63,96-62,03=$ 1,93), pada kelas eksperimen di atas kelas kontrol. Selisih rata-rata tersebut membuktikan bahwa penggunaan aplikasi edlink memiliki pengaruh untuk mengembangkan kemandirian mahasiswa.

Berlandaskan uraian sebelumnya maka disimpulkan bahwa kemandirian belajar mahasiswa kelompok eksperimen menunjukkan lebih tinggi dibanding kelompok kontrol. Jikalau dilihat berdasar rata-rata pretest kelas kontrol dan kelas eksperimen memiliki nilai yang tidak jauh berbeda, akan tetapi hasil posttest membuktikan kelas eksperimen lebih tinggi dibanding kelas kontrol. Hal ini membuktikan bahwa penggunaan aplikasi edlink memiliki pengaruh lebih baik guna 
meningkatkan kemandirian belajar mahasiswa terhadap pembelajaran daring dibanding kelas kontrol yang menggunakan aplikasi lain.

\section{Perbedaan Kemandirian Belajar Mahasiswa PGSD dengan \\ Menggunakan Aplikasi Edlink dan WhasApp}

Ringkasan hasil perhitungan uji-t dapat dilihat pada tabel 2 sebagai berikut:

Tabel 2. Hasil perhitungan uji-t

\begin{tabular}{ccccc}
\hline No & $\begin{array}{c}\text { Kelompok yang } \\
\text { dibandingkan }\end{array}$ & $\mathbf{t}_{\text {hitung }}$ & $\mathbf{t}_{\text {tabel } \mathbf{0 , 0 5}}$ & Keterangan \\
\hline Gain & $\begin{array}{c}\text { Gain } \\
\text { dan control }\end{array}$ & 4,196 & 2,00758 & Signifikan \\
\hline
\end{tabular}

Sumber: Data Primer Hasil Penelitian,

2020

Berlandaskan tabel 4.2 membuktikan

bahwa perhitungan uji-t membuktikan hasil perhitungan tentang perbedaan keefektifan antara kedua metode pembelajaran secara keseluruhan bahwa $\mathrm{t}_{\text {hitung }}=4,196>\mathrm{t}_{\text {tabel }}=2,00758$ pada taraf Signifikan $\alpha=0.05$, dengan demikian $\mathrm{H}_{0}$ ditolak dan hipotesis alternatif $\mathrm{H}_{1}$ diterima. Kemandirian belajar mahasiswa dengan menggunakan aplikasi edlink memiliki nilai lebih tinggi daripada kelompok mahasiswa yang menggunakan aplikasi whatsapp.

Nilai perhitungan uji-t dapat ditarik simpulan bahwa ada perbedaan pengaruh yang secara signifikan antara kelompok mahasiswa yang menggunakan aplikasi edlink dan kelompok mahasiswa yang menggunakan aplikasi whatsapp terhadap kemandirian belajar. Maka dari itu, kemandirian belajar yang menggunakan aplikasi edlink lebih menarik secara realitas daripada menggunakan aplikasi whatsapp. perihal hipotesis penelitian ini secara menyeluruh yaitu kemandirian belajar yang menggunakan aplikasi edlink lebih tinggi daripada kelompok mahasiswa yang menggunakan aplikasi whatsapp.

\section{PEMBAHASAN}

1. Gambaran Kemandirian Belajar Mahasiswa PGSD Sebelum Penggunaan Aplikasi Edlink dan Sesudah Penggunaan Aplikasi Edlink

Nilai data rata-rata posttest pada kelas eksperimen secara menyeluruh, sebesar 63,96 dan standar deviasi sebesar 1,933. Berlandaskan data pretes bisa dilihat bahwa, ada 7 mahasiswa pada rentang 5266 dengan kategori tinggi, dan terdapat 20 mahasiswa pada rentang 37-51 dengan kategori sedang. Dengan demikian menunjukkan target peningkatan kemandirian belajar yang diharapkan. Pada kategori rendah tidak ada lagi mahasiswa berada dikategori tersebut. Sementara itu posttest pada kelas kontrol hasil data ratarata secara menyeluruh sebesar 62,03 dan standar deviasi sebesar 3,923. Berlandaskan data pretes bisa dilihat 
bahwa, ada 27 mahasiswa berada pada rentang 37-51 berada kategori sedang. perihal ini memperlihatkan sebaran data posttest kelas eksperimen dan kelas kontrol sangat berbeda jauh.

$$
\text { Jika dibandingkan data }
$$

kemandirian belajar mahasiswa yang menggunakan aplikasi edlink dengan kemandirian belajar mahasiswa yang menggunakan aplikasi whatsapp menampilkan keunggulan pada kelas eksperimen bahwa mahasiswa yang memiliki kemandirian belajar tidak ada lagi dikategori rendah sementara di kelas kontrol semua mahasiswa berada pada kategori sedang. Hal ini disebabkan mahasiswa belum memperhatikan keunggulan serta perbedaan pada aplikasi edlink dibanding aplikasi whatsapp yang mempengaruhi proses pembelajaran daring. Penyajian materi menggunakan via online/daring dapat bersifat interaktif sehingga mahasiswa dapat berinteraksi dengan komputer sebagai media belajarnya. Pendapat (Rosenberg, 2001) menjelaskan bahwa E-learning mengirimkan serangkaian solusi yang dapat meningkatkan pengetahuan dan keterampilan pada penggunaan teknologi internet. Dapat disimpulkan pemberian materi pelajaran dan latihan soal maupun tugas pada aplikasi Edlink memberikan motivasi mahasiswa untuk mempelajari secara berkala materi yang telah diberikan dalam perkuliahan daring untuk mempersiapkan diri mengikuti ujian.

\section{Perbedaan Kemandirian Belajar Mahasiswa PGSD dengan} Menggunakan Aplikasi Edlink dan WhasApp

Berdasarkan pengujian hipotesis dengan uji $t$ diperoleh nilai t hitung sebesar $\mathrm{t}_{\mathrm{o}}=4$,196. Apabila dibandingkan dengan nilai $t$ tabel pada taraf signifikan 5\% maka diperoleh $\mathrm{t}$ tabel sebesar $\mathrm{t}_{\alpha}=2,00758$ sehingga bisa dinyatakan bahwa $t_{0}>t_{\alpha}=$ 4,196>2,00758. perihal ini membuktikan bahwa $\mathrm{H}_{0}$ pada penelitian ini ditolak. Dari hasil ini, dapat ditarik simpulan bahwa pemberian perlakuan dengan menggunakan aplikasi edlink dapat meningkatkan kemandirian belajar mahasiswa PSGD FKIP Universitas Islam Makassar.

Setelah dilakukan pembelajaran menggunakan aplikasi edlink pada kelompok eksperimen dan kelompok kontrol dengan menggunakan aplikasi whatsapp dapat dilihat kemandirian belajar kedua kelompok tersebut memiliki perbedaan secara real. Hal ini dibuktikan dengan hasil uji $t_{\text {hitung }}$ sebesar 4,196 dengan nilai $t_{\text {tabel }}=2,00758$. Karena $t_{\text {hitung }}>t_{\text {tabel }}$ maka $\mathrm{H}_{0}$ ditolak. Atau dapat disimpulkan pada kelas eksperimen ada pengaruh signifikan/positif terhadap kemandirian belajar. 
Berdasarkan hasil penghitungan dapat dilihat bahwa kemandirian belajar kelas eksperimen lebih unggul dibandingkan kelas kontrol dengan nilai rata-rata kelas eksperimen sebesar 63,96 dan kelas kontrol sebesar 62,03. Sehingga pembelajaran daring menggunakan aplikasi edlink berpengaruh positif terhadap kemandirian belajar mahasiswa PGSD FKIP Universitas Islam Makassar.

Selisih rata-rata kemandirian belajar mahasiswa pada kelas eksperimen dan kelas kontrol disebabkan karena adanya perbedaan perlakuan. Pada kelas eksperimen yang diberi pembelajaran melalui aplikasi edlink. perihal tersebut memberikan pengaruh positif karena aplikasi edlink merupakan aplikasi yang memudahkan mahasiswa dan dosen/pendidik dalam kegiatan belajar mengajar. Kemudahan yang didapatkan yakni presensi mahasiswa cukup dengan memakai smartphone, berbagi informasi materi perkuliahan atau pelajaran, dan memberikan tugas menjadi lebih mudah hanya lewat genggaman, ada fitur jadwal perkuliahan sehingga tidak perlu merasa khawatir akan lupa jadwal perkuliahan karena adanya notifikasi yang akan selalu mengingatkan mahasiswa ataupun dosen. Evaluasi belajar lebih fun \& efektif, dosen bisa memanfaatkan kuis interaktif sehingga proses pembelajarannya terkesan menarik dan menyenangkan.
Berbeda halnya dalam pembelajaran yang menggunakan aplikasi whatsapp mahasiswa lebih banyak melaksanakan perkuliahan daring dengan video call konferensi yang terbatas maksimal 8 orang saja, akhirnya cenderung pasif. Proses belajar mengajar ini, dosen hanya mengirimkan materi dan tugas saja. Mahasiswa masih cenderung kurang berminat dalam mengikuti pembelajaran menjadikan mahasiswa kurang memahami secara menyeluruh intisari dari materi perkuliahan tersebut.

Perbedaan cara dosen dalam menyampaikan materi belajar menimbulkan perbedaan aktivitas mahasiswa pada kelas eksperimen ataupun kelas kontrol. Kelas yang proses belajar mengajarnya menggunakan aplikasi edlink, mahasiswa lebih cenderung aktif selama proses pembelajaran berlangsung. Sementara kelas yang menggunakan aplikasi whatsapp, mahasiswa cenderung pasif, baik dalam merespon materi pelajaran maupun mengerjakan tugas-tugas yang telah diinstruksikan oleh dosen. Sejalan pendapat (Novandini \& Luta, 2019) yang menyatakan bahwa kegiatan pembelajaran tidak mesti selalu bertatap muka secara langsung, karena di zaman sekarang banyak aplikasi-aplikasi modern dapat dimanfaatkan untuk membantu memudahkan dosen/pendidik dan 
mahasiswa/peserta didik, seperti dengan memanfaatkan aplikasi Edlink.

Hal ini sejalan dengan penelitian terdahulu dilakukan oleh (Novandini \& Luta, 2019) dengan Pemanfaatan Kelas Virtual Sevima Edlink Untuk Memotivasi Mahasiswa Pendidikan Matematika Semester 1 Matakuliah Aljabar \& Trigonometri. Hasil penelitiannya menunjukkan pemanfaatan aplikasi Sevima Edlink cukup efektif dalam memotivasi dan membantu mahasiswa dalam belajar untuk mempersiapkan ujian remidi.

Data-data tersebut dipertegas dengan adanya hasil analisis deskriptif dan inferensial yang menjabarkan adanya perbedaan yang signifikan antara kelas eksperimen dengan kelas kontrol. Proses belajar mengajar daring menggunakan aplikasi edlink memberikan hasil yang berbeda dengan proses belajar mengajar daring yang menggunakan aplikasi whasapp. Perihal ini disebabkan karena perbedaan perlakuan yang diberikan pada kelas eksperimen dan kelas kontrol.

Pembelajaran diawali sesuai dengan langkah-langkah aplikasi edlink pada kelas eksperimen yang diberi perlakuan menggunakan aplikasi edlink. Proses belajar mengajar ini efektif digunakan karena menyertakan seluruh mahasiswa dalam proses belajar, seluruh mahasiswa memiliki kesempatan yang sama mengutarakan gagasannya dalam kuis interaktif. Senada pendapat (Sanjaya, 2014) bahwa metode adalah kaidah yang digunakan untuk menerapkan rencana yang telah disusun dalam kegiatan aktual agar tujuan yang telah disusun berhasil secara optimal. Sehingga metode belajar efektif diterapkan untuk meningkatkan kemandirian belajar.

Berdasarkan hasil tinjauan yang dilakukan oleh peneliti pada kelompok kontrol, dosen tersebut lebih banyak mengirimkan materi pembelajaran di grup WA. Sehingga mahasiswa merasa jenuh karena waktu yang ia habiskan hanya membaca materi pembelajaran. Hal tersebut membuat mahasiswa kelas kontrol memiliki kemandirian belajar lebih rendah dibandingkan yang diperoleh pada kelas ekperimen.

Berlandaskan penjelasan di atas, maka penggunaan aplikasi edlink dapat diaplikasikan untuk meningkatkan kemandirian belajar mahasiswa khususnya pada mahassiswa Pendidikan Guru Sekolah Dasar FKIP Universitas Islam Makassar (UIM).

\section{SIMPULAN}

Pada bagian ini disajikan kesimpulan sebagai berikut:

1. Kemandirian belajar mahasiswa PGSD FKIP UIM dalam pembelajaran daring dengan penggunaan aplikasi edlink (eksperimen) pada pretest berada pada kategori rendah dan pada postest 
berada pada kategori tinggi sedangkan kelas kontrol pada pretest berada pada kategori rendah dan postest berada pada kategori sedang.

2. Terdapat perbedaan kemandirian belajar pada kelas eksperimen yang menggunakan aplikasi edlink dan kelas kontrol menggunakan aplikasi lain, sehingga penggunaan aplikasi edlink memiliki pengaruh yang signifikan terhadap kemandirian belajar mahasiswa PGSD FKIP Universitas Islam Makassar.

\section{DAFTAR PUSTAKA}

Darmayanti, T., Islam, S., \& Asandhimitra. (2004). Pendidikan tinggi jarak jauh: Kemandirian belajar pada PTJJ. Jakarta: Pusat Penerbitan Universitas Terbuka.

Hartanto, A. (2010). Panduan Aplikasi Smartphone. Jakarta: Gramedia Pustaka Utama.

Haryono, A. (2001). Belajar mandiri konsep dan penerapannya dalam sistem pendidikan dan pelatihan terbuka/jarak jauh. Jurnal Pendidikan Terbuka Dan Jarak Jauh, 2(2 ), 137-161.

Novandini, C. D., \& Luta, M. W. D. (2019). Pemanfaatan Kelas Virtual Sevima Edlink Untuk Memotivasi Mahasiswa Pendidikan Matematika Semester 1 Matakuliah Aljabar \&
Trigonometri. Prosiding Seminar Nasional Etnomatnesia.

Rachmayani, D. (2014). Penerapan Pembelajaran Reciprocal Teaching untuk Meningkatkan Kemampuan Komunikasi Matematis dan Kemandirian Belajar Matematika Siswa. Jurnal Pendidikan UNSIKA, 2(1).

Rahmasari, A. F., Setiawan, F., \& Faradita, M. N. (2020). Pengaruh Pembelajaran Online Terhadap Kemandirian Belajar Siswa Kelas II SD Muhammadiyah 17 Surabaya di Tengah Pandemi Covid-19. Inventa: Jurnal Pendidikan Guru Sekolah Dasar, 04 No 2.

Rosenberg, M. (2001). E-Learning. Strategies for Delivering Knowledge in The Digital Age. USA:McGrawHill Companies.

$\begin{array}{lll}\text { Sanjaya, } & \text { W. (2014). Strategi }\end{array}$ Pembelajaran. Jakarta: Kencana Prenada Media Group.

Suryadi, E., Ginanjar, M. H., \& Priyatna, M. (2018). Penggunaan Sosial Media Whatsapp Dan Pengaruhnya Terhadap Disiplin Belajar Peserta Didik Pada Mata Pelajaran Pendidikan Agama Islam. Edukasi Islam, Jurnal Pendidikan Islam, Vol.07, No. 1.

Syah, Muhibbin. (2014). Psikologi Pendidikan Dengan Pendekatan 
Baru. Bandung: PT. Remaja Rosdakarya.

Tahar, I., \& Enceng. (2006). Hubungan Kemandirian Belajar Dan Hasil Belajar Pada Pendidikan Jarak Jauh. Jurnal Pendidikan Terbuka Dan Jarak Jauh, 7, Nomor 2.

Tirtaraharja, U., \& Sulo Lipu La Sulo. (2005). Pengantar Pendidikan. Jakarta: Rineka Cipta.

Triwiyanto, T. (2021). Pengantar Pendidikan. Malang: Bumi aksara. 